\title{
The Billefjorden Fault Zone north of Spitsbergen: a major terrane boundary?
}

\author{
Jean-Baptiste P. Koehl ${ }^{1,2,3,4}$ \& Lis Allaart ${ }^{2,5,6}$ \\ ${ }^{1}$ Centre for Earth Evolution and Dynamics, University of Oslo, Oslo, Norway \\ 2Department of Geosciences, UiT The Arctic University of Norway, Tromsø, Norway \\ ${ }^{3}$ Research Centre for Arctic Petroleum Exploration, UiT The Arctic University of Norway, Tromsø, Norway \\ ${ }^{4}$ Centre for Arctic Gas Hydrate, Environment and Climate, UiT The Arctic University of Norway, Troms $\varnothing$, Norway \\ ${ }^{5}$ Department of Geoscience, Århus University, Århus, Denmark \\ ${ }^{6}$ Department of Arctic Geology, University Centre in Svalbard, Longyearbyen, Norway
}

\begin{abstract}
The Billefjorden Fault Zone is a major terrane boundary in the Norwegian Arctic. The fault separates basement rocks of Svalbard's north-eastern and north-western terranes that recorded discrete Precambrian tectonothermal histories and were accreted, intensely deformed and metamorphosed during the Caledonian Orogeny. Although the fault represents a major, crustal-scale tectonic boundary, its northward extent is not well constrained. The present short contribution addresses this issue and presents new seismic mapping of structures and rock units north of Wijdefjorden, where the Billefjorden Fault Zone may continue. This study shows that there is no evidence for major faulting of the top-basement reflection, and therefore, that the Billefjorden Fault Zone may die out within WijdefjordenAustfjorden, step $\geq 20 \mathrm{~km}$ laterally, or be invisible on the presented seismic data. Seismic data also suggest that Caledonian basement rocks in Ny-Friesland (north-eastern terrane) are not significantly different from basement rocks below the Devonian Graben in Andrée Land (north-western terrane). Potential implications include the absence of a major terrane boundary in northern Spitsbergen.
\end{abstract}

\begin{abstract}
Keywords
Fault; basement terranes; seismic facies; Svalbard; tectonic

\section{Correspondence}

Jean-Baptiste P. Koehl, Centre for Earth Evolution and Dynamics, University of Oslo, PO Box 1028 Blindern, NO-0315 Oslo,

Norway. E-mail: jeanbaptiste.koehl@gmail.com
\end{abstract}

\section{Abbreviations}

TWT: Two-Way Time

To access the supplementary material, please visit the article landing page

\section{Introduction}

The Svalbard Archipelago consists of three basement terranes with different tectonic histories (Harland et al. 1992; Labrousse et al. 2008; Mazur et al. 2009). These terranes are separated by lithospheric boundary faults. Among these faults, the Billefjorden Fault Zone (see location on Fig. 1) juxtaposed granitic Palaeoproterozoic basement rocks of the north-eastern basement terrane (Fleming \& Edmonds 1941; Gee et al. 1992; Balashov et al. 1993) against sedimentary rocks of the northern Devonian Graben that were deposited onto eclogite, migmatitic schists and metasedimentary rocks of the north-western basement terrane (Gee \& Hjelle 1966; Gjelsvik 1979; Labrousse et al. 2008; Fig. 1b). Both basement terranes were deformed and metamorphosed during the mid-Palaeozoic Caledonian Orogeny (Dallmeyer et al. 1990; Gee \& Page 1994). In the north-eastern terrane
(Ny-Friesland), this resulted in the formation of the Atomfjella Antiform, a major gently north-plunging antiformal thrust stack $25 \mathrm{~km}$ in width (see Fig. 1 for location; Gee et al. 1994; Witt-Nilsson et al. 1998). In the north-western terrane, Caledonian deformation possibly resulted in large-scale folding of basement rocks into a north-south-trending, north-plunging anticline 10-15 $\mathrm{km}$ in width, the Bockfjorden Anticline (location shown in Fig. 1; Gee \& Hjelle 1966; Gjelsvik 1979). Exhumation of basement rocks in the Bockfjorden Anticline may also have occurred during the late Silurian-Devonian extensional collapse, Late Devonian Ellesmerian contraction and/or early Cenozoic Eurekan contraction (Gjelsvik 1979; Braathen et al. 2018; Dallmann \& Piepjohn 2018, 2020).

The Billefjorden Fault Zone is thought to have formed during Ellesmerian/Svalbardian top-west thrusting of Ny-Friesland basement rocks onto collapse sedimentary 
deposits of the Devonian Graben in the northern Spitsbergen (Harland et al. 1974; McCann 2000; Piepjohn 2000). Alternatively, the Billefjorden Fault Zone formed during the Caledonian Orogeny and was reactivated as a normal fault during the late-post-orogenic collapse, defining the eastern boundary of the Devonian Graben (Manby \& Lyberis 1992). The fault was reactivated during subsequent tectonic events, including Carboniferous extension (Braathen et al. 2011; Smyrak-Sikora et al. 2018) and early Cenozoic Eurekan contraction (Major $\delta$ Nagy 1972; Harland et al. 1974; Haremo et al. 1990).

In Billefjorden and Sassenfjorden, the Billefjorden Fault Zone is well constrained and disrupts seismic reflections (see location in Fig. 1; Bæelum \& Braathen 2012; Kubiak 2020; Nergård 2020). In the south of Sassenfjorden, seismic, magnetic and structural field data suggest that the fault proceeds onshore Nordenskiöld Land and Heer Land, and into Storfjorden and the northern Barents Sea offshore (location shown in Fig. 1; Major \& Nagy 1972; Haremo et al. 1990; Skilbrei 1992; Bæelum \& Braathen 2012). In the north, the Billefjorden Fault Zone can be traced onshore into Odellfjellet (Fig. 1). Farther north, the fault is believed to continue offshore in nearshore fjords (Austfjorden, Wijdefjorden; Fig. 1). However, its continuation north of Spitsbergen and interaction with known east-west-striking, late Cenozoic normal faults (e.g., Moffen Fault Zone; Eiken 1992; Geissler \& Jokat 2004) is poorly constrained, and only a few studies have attempted seismic mapping of the fault in this area (e.g., Kowalewski et al. 1990; Czuba et al. 2004, 2005; Geissler \& Jokat 2004; Roy 2007, figures 101-102; Jokat et al. 2008; Geissler et al. 2011).

The present contribution presents new seismic mapping north of Wijdefjorden and briefly discusses potential implications for the continuation of the Billefjorden Fault Zone and for major terrane boundaries in Svalbard. Note

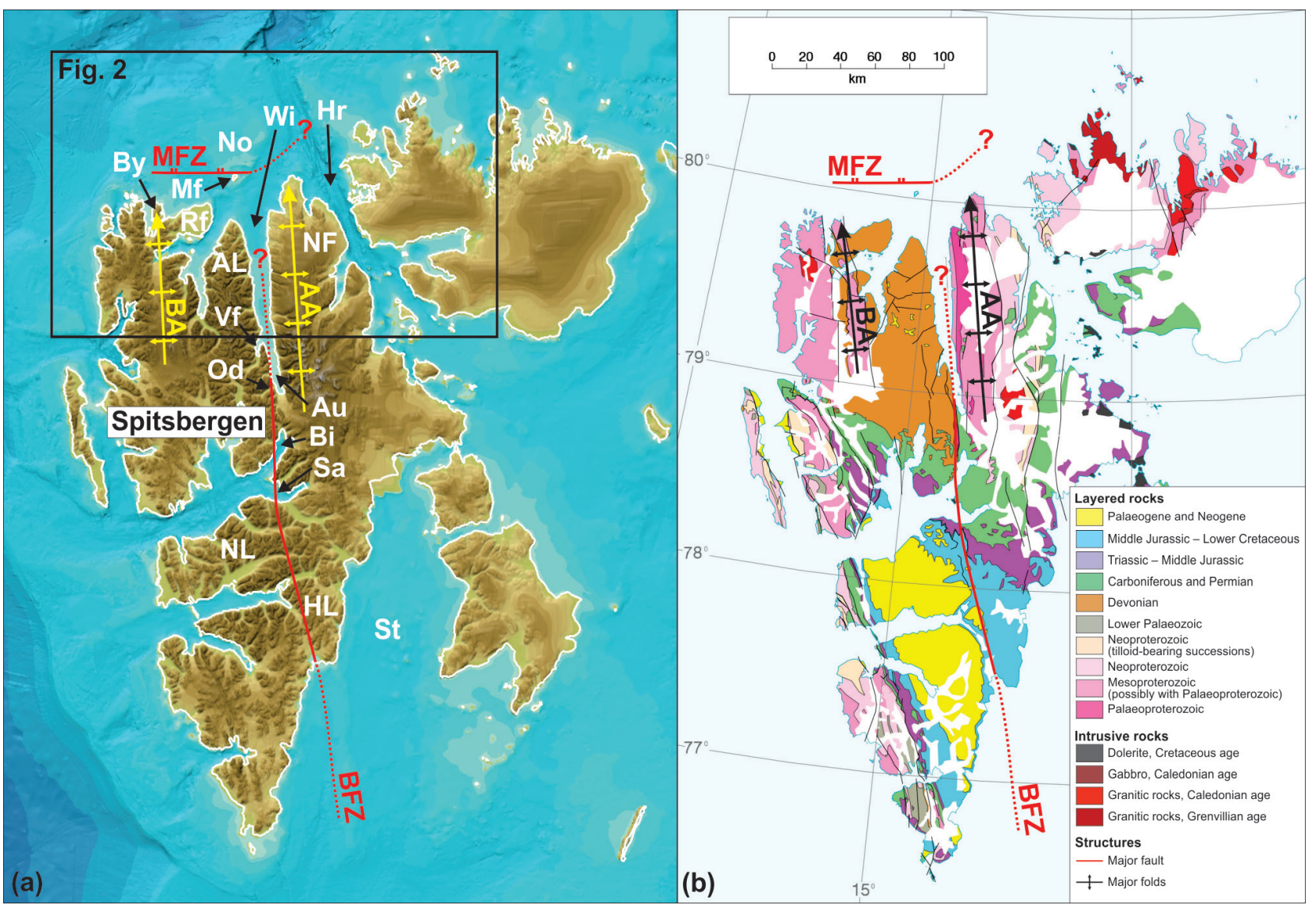

Fig. 1 (a) Base image from the International Bathymetric Chart of the Arctic Ocean (Jakobsson et al. 2012), showing Spitsbergen and the location of major structural elements in the study area (black frame). Abbreviations: AA: Atomfjella Antiform; AL: Andrée Land; Au: Austfjorden; BA: Bockfjorden Anticline; BFZ: Billefjorden Fault Zone; Bi: Billefjorden; By: Biscayarhalvøya; HL: Heel Land; Hr: Hinlopenrenna; KP: Kapp Petermann; Mf: Moffen; MFZ: Moffen Fault Zone; NF: Ny-Friesland; NL: Nordenskiöld Land; No: Norskebanken; Od: Odellfjellet; Rf: Reinsdyrflya; Sa: Sassenfjorden; St: Storfjorden; Vf: Vestfjorden; Wi: Wijdefjorden. (b) Geological map of Svalbard after Dallmann (2015). 
that the term "basement" refers to rocks older than the Caledonian Orogeny. Seismic reflection data used in the present study are from the DISKOS database. The analysed profiles show relatively high resolution, and lines trending east-west (i.e., orthogonal to the Billefjorden Fault Zone) are ideal to identify major disruptions of the bedrock related to brittle faulting along the Billefjorden Fault Zone at the mouth of Wijdefjorden (Fig. 2). Highresolution versions of the figures are available on DataverseNO at doi.org/10.18710/LP3YMQ.

\section{Results and interpretation}

Analysis of seismic data north of Wijdefjorden shows two distinct seismic units characterized by distinct seismic facies, and two major reflections (including the seafloor). Each seismic facies and reflection is described and then interpreted in the present section.

\section{Description lower seismic unit (facies 1)}

The lower seismic unit shows a chaotic facies (seismic facies 1) and typically consists of steeply east- and west-dipping, arcuate and low- to moderate-amplitude reflections (Fig. 3a and red lines in Fig. 3b-c; see
Supplementary Fig. S1 for uninterpreted seismic profile and Supplementary Fig. S2 for more interpreted seismic data). In places, these arcuate reflections are continuous for up to $1 \mathrm{~km}$, show moderate to high amplitude and curve upwards and downwards, defining minor (geometrical) peaks and troughs with both symmetric and asymmetric geometries and hundreds of metres wavelength (red lines in Fig. 3a-c and Supplementary Figs. S1, S2). These are particularly well developed in the western part of the seismic profile. In the east, regularly spaced, moderate amplitude reflections dominate and occur down to one second (TWT). These display comparable attitude to the seafloor reflection, though with gradually increasing vertical amplitude at depth (Fig. 3c).

\section{Interpretation lower seismic unit (facies 1)}

Moderate-high amplitude, arcuate, curving up and down reflections display varied and unique shapes (no reflections show exactly the same pattern) with consistently similar geometries throughout the lower seismic unit despite seismic artifacts (e.g., multiples; Fig. 3). This suggests that they do not represent noise. In addition, these reflections are typically strongly similar in shape, size and attitude to fold structures on seismic data (Ji \&

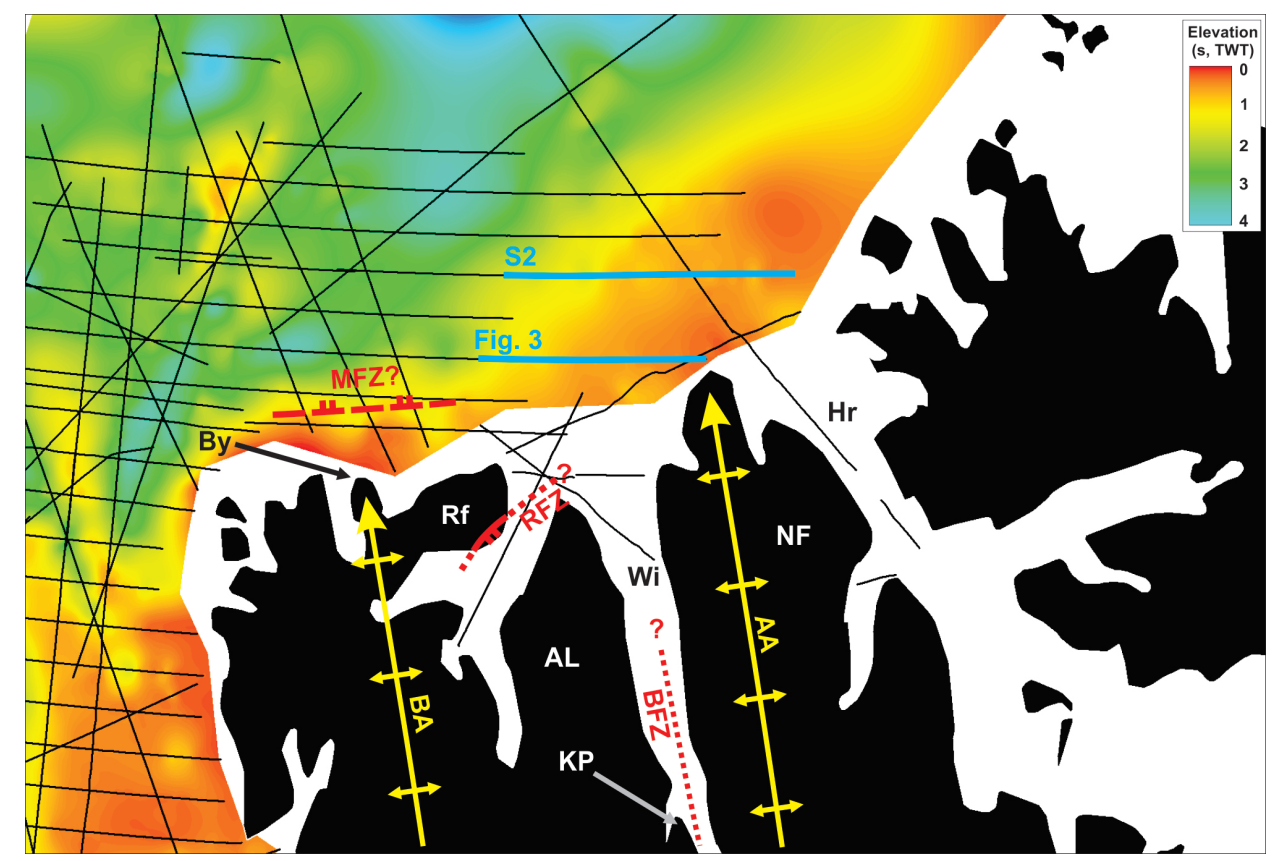

Fig. 2 TWT map of the top-basement reflection around northern Spitsbergen. Note the trace of major gently north-plunging basement folds (yellow lines) and the possible continuation of the Billefjorden Fault Zone in Wijdefjorden (dotted red line). The locations of areas shown in Fig. 3 and Supplementary Fig. S2 are indicated in blue, and black lines show the location of all the other seismic lines used in the present study. Abbreviations: AA: Atomfjella Antiform; AL: Andrée Land; BA: Bockfjorden Anticline; BFZ: Billefjorden Fault Zone; By: Biscayarhalvøya; Hr: Hinlopenrenna; KP: Kapp Petermann; MFZ: Moffen Fault Zone; NF: Ny-Friesland; Rf: Reinsdyrflya; RFZ: Reinstranda Fault Zone; Wi: Wijdefjorden. 
Long 2006) and to north-south-trending fold structures with 1-2 km wide wavelength within basement rocks in Ny-Friesland (Harland et al. 1992, figure 4; Witt-Nilsson et al. 1998). Furthermore, seismic velocity obtained for this rock unit in north of Spitsbergen is $\geq 5.5 \mathrm{~km} / \mathrm{s}$, that is, comparable to basement rocks in Spitsbergen (Geissler \& Jokat 2004; Czuba et al. 2005). The lower seismic unit characterized by seismic facies 1 is, therefore, interpreted as tightly folded basement rocks. In adjacent onshore areas of Ny-Friesland, previous field studies recorded the presence of Palaeoproterozoic rocks of the Atomfjella Antiform, which were tightly folded and metamorphosed during the Caledonian Orogeny (Gee et al. 1994; Witt-Nilsson et al. 1998). Because of the proximity with the interpreted basement rocks off the coast of northern Spitsbergen, which crop out at seafloor level near the northern tip of Ny-Friesland (Fig. 3a, c), offshore basement rocks are thought to be comparable to those of the Atomfjella Antiform. Note the coincidence of antiformal fold structures in basement rocks with antiformal structures in overlying seismic units (Fig. 3, Supplementary Figs. S1, S2). The moderate-amplitude reflections that display geometries analogous to the seafloor are interpreted as multiples.

\section{Description upper seismic unit (facies 2)}

Seismic facies 2 (uppermost facies) is made up with laterally continuous, gently undulating, moderate amplitude reflections. In places, these reflections terminate against each other laterally (onlaps) and upwards (toplaps), and against a major reflection downwards (downlaps; see yellow half-arrows in Fig. 3a-b). In the upper part, seismic reflections of seismic facies 2 display low amplitude, dip gently to the west and are truncated by linear, flat-lying reflections that mimic the morphology of the seafloor (Fig. 3b). The uppermost portion $(<0.25$ second TWT) of the upper seismic unit shows continuous, high-amplitude reflections.

\section{Interpretation upper seismic unit (facies 2)}

Based on their relatively good lateral continuity, on their undulating to gently west-dipping geometries and on the
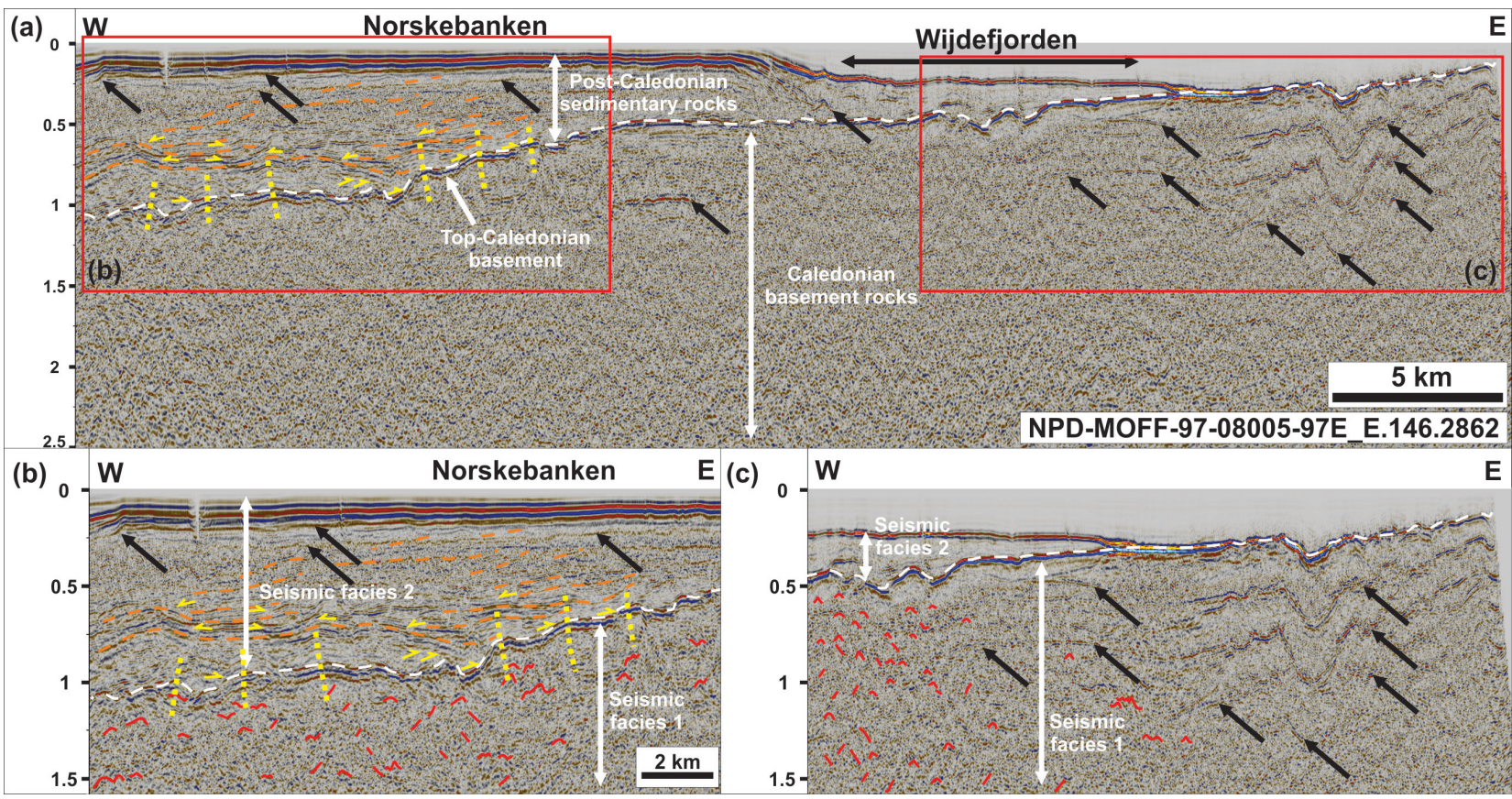

Fig. 3 (a) East-west-trending seismic section north of Spitsbergen, across Norskebanken and the mouth of Wijdefjorden. The profile shows the top-basement reflection (dashed white line) and a westwards thickening post-Caledonian (Devonian?) sedimentary succession. Black arrows denote multiples and dotted yellow lines fold axes. See Fig. 2 for location; (b) and (c) are zooms in the western and eastern parts of (a), respectively. In (b), a detailed view of the chaotic aspect and associated steeply east- and west-dipping reflections (red lines) characterizing seismic facies 1 (Caledonian basement rocks) is shown, whereas (c) shows gently undulating to gently west-dipping moderate amplitude reflections (dashed orange lines) and onlaps, toplaps and downlaps geometries (yellow half-arrows) characteristic of seismic facies 2 (post-Caledonian sedimentary rocks). Notice that the shallow seafloor reflection resulted in several multiples (black arrows). 
observed seismic onlaps, downlaps and toplaps, the reflections characterizing seismic facies 2 are interpreted as sedimentary strata. Considering the geology of nearby onshore areas like Andrée Land and Reinsdyrflya (see Figs. 1 and 2 for location) where the presence of the Devonian Graben deposits, several kilometres in thickness, is well documented by previous field studies (Murascov \& Mokin 1979; Manby et al. 1994; Friend et al. 1997; Dallmann \& Piepjohn 2020), these offshore sedimentary strata are believed to correspond to post-Caledonian sedimentary rocks, most probably of Devonian age. This interpretation is supported by the analysis of seismic refraction data in nearby offshore areas (Ritzmann $\delta$ Jokat 2003) and by the seismic stratigraphy established by Geissler $\&$ Jokat (2004) for the continental margin north of Spitsbergen (lower part of their unit NoB-1 with seismic velocity $>3 \mathrm{~km} / \mathrm{s}$ ). The uppermost, flat-lying, high-amplitude reflections just below the seafloor most likely represent younger Cenozoic sediments. However, some of these flat-lying reflections mimic the shallow seafloor and, therefore, include multiples (black arrows in Figs. 3a-b). It is, therefore, difficult to assess the thickness of the Cenozoic sediments.

\section{Description major reflection}

The two seismic successions defined by seismic facies 1 and 2 are separated by a major rugged reflection. In the west, this reflection occurs at a depth of approximately one second (TWT), whereas it becomes gradually shallower and eventually merges with the seafloor reflection towards the east (Fig. 3). This reflection displays a relatively homogeneous geometry throughout the study area, curving up and down gently with a wavelength of 1-2 km (dotted yellow lines in Fig. 3a-b), and typically appears as a high- to moderate-amplitude seismic peak (red; i.e., positive reflection, like the seafloor). From a regional perspective, this major reflection gently deepens towards the west and north-west (Fig. 2).

\section{Interpretation major boundary}

The rugged appearance of this major reflection suggests that it represents a major erosional unconformity. In addition, the positive character of the reflection strongly suggests that rocks characterized by seismic facies 1 (lower seismic unit) are relatively denser than rocks defining seismic facies 2 (upper seismic unit). Based on the geology of nearby onshore areas, this reflection is interpreted as the boundary between folded and metamorphosed Caledonian basement rocks and overlying, mildly deformed, post-Caledonian sedimentary successions. This is supported by published basement sonobuoy velocities north of Spitsbergen (Geissler \& Jokat 2004). The reflection is referred to as the top-basement reflection in the discussion. Considering the complex tectonic history of Caledonian basement and Devonian sedimentary rocks in adjacent onshore areas (e.g., Gee et al. 1994; Dallmann \& Piepjohn 2020), the curving attitude of this major reflection is interpreted as the seismic expression of 1-2 km wide, upright fold structures (dotted yellow lines in Fig. 3a-b). Since these gentle upright folds also appear to propagate into the overlying post-Caledonian sedimentary strata, they are likely post-Caledonian in age, that is, possibly Devonian and/or early Cenozoic.

\section{Discussion}

Despite tentative interpretation by earlier workers (Kowalewski et al. 1990; Roy 2007), the present analysis of more recent, deep-penetrating seismic data north of Wijdefjorden shows no clear sign of faulting (Fig. 3a-c, Supplementary Figs. S1, S2). On the contrary, the top-basement unconformity can be traced across the northward prolongation of Wijdefjorden and throughout the study area north of Spitsbergen without any significant disruption, or any change in seismic character (Fig. 3a-c, Supplementary Figs. S 1, S2; see Supplementary material for further discussion and expected seismic character). Instead of abrupt depth variation, which is typically observed across major faults (see Supplementary material for further discussion and estimate of the expected offset), the reflection gently deepens westwards and north-westwards (Fig. 2). Allaart et al. (2020) reported north-south-trending ridges on bathymetric data in northern Wijdefjorden, but these consist either of recent glacial deposits following the trend of the fjord and are associated with a flat-lying top-basement reflection (Allaart et al. 2020, figure 5) or of tightly folded, subvertical basement units of the Atomfjella Antiform (Manby 1990; Witt-Nilsson et al. 1998). Based on these observations, we discuss three possible scenarios for the Billefjorden Fault Zone north of Wijdefjorden.

Since there is no sign of faulting, the Billefjorden Fault Zone probably dies out northwards within Wijdefjorden or Austfjorden (possibly south of Kapp Petermann; see Fig. 1 and Fig. 2 for location). In this scenario, displacement along the fault zone would decrease northwards towards the fault tip. This would imply that the Billefjorden Fault Zone does not represent a major terrane boundary. This is supported by deep seismic sounding, which shows no sign of abrupt lateral variation in seismic velocity at the mouth of Wijdefjorden or in Austfjorden, that is, no offset of high velocity basement rocks against relatively low velocity post-Caledonian sedimentary rocks (Czuba et al. 2004, 2005). The lack of deep-penetrating seismic sections 
orthogonal to the fault in Wijdefjorden and Austfjorden does not allow further testing of this model.

Alternatively, the fault may step laterally by $20 \mathrm{~km}$ or more, that is, in Hinlopenrenna to the east or west of the studied seismic profiles (Fig. 2). Such behaviour is common for major strike-slip faults (e.g., Sylvester 1988; Nilsen \& Sylvester 1995) and was previously reported along the Billefjorden Fault Zone in Billefjorden and Sassenfjorden (Bælum \& Braathen 2012). A potential south-east-dipping fault was mapped in south-eastern Reinsdyrflya by Dallmann \& Piepjohn (2020, figure 33), and this fault could possibly offset the Billefjorden Fault Zone laterally in northern Wijdefjorden. However, the Reinstranda Fault Zone is a normal fault (Dallmann \& Piepjohn 2020) and, hence, is highly unlikely to have accommodated kilometre-scale lateral displacement. This is also the case of the Moffen Fault Zone, which is thought to be a late Cenozoic normal fault (Eiken 1992; Geissler \& Jokat 2004; Geissler et al. 2011) and whose north-east-south-west-striking segment was not identified on seismic data (present study), thus suggesting that the fault dies out west of Wijdefjorden. In addition, no major north-south-striking fault and no major offset of the top-basement reflection were observed on seismic data in areas east and west of the mouth of Wijdefjorden, and seismic velocities do not show any abrupt lateral variation characteristic of the presence of a major fault (Czuba et al. 2004, 2005; Czuba 2007). Moreover, studies along onshore portions of the Billefjorden Fault Zone showed that large-scale strikeslip movements are unlikely (Lamar et al. 1986; Lamar \& Douglass 1995; Piepjohn 2000; Michalski et al. 2012). Furthermore, the fault steps in BillefjordenSassenfjorden are in the order of $1-3 \mathrm{~km}$. A major step of the fault $\geq 20 \mathrm{~km}$ north of Spitsbergen is, therefore, unlikely.

Another possibility is that the fault is invisible on seismic data and juxtaposes two basement terranes with strongly similar seismic signatures. However, strong lithological differences between basement rocks in north-eastern (Ny-Friesland; Harland et al. 1993; Gee et al. 1994; Witt-Nilsson et al. 1998) and north-western Spitsbergen (Biscayarhalvøya; Gee \& Hjelle 1966; Gjelsvik 1979; Labrousse et al. 2008) suggest otherwise. In addition, the undisrupted character of the top-basement reflection north of Wijdefjorden contrasts with the complex post-Caledonian reactivation history of the Billefjorden Fault Zone recorded by field studies in Spitsbergen (Harland et al. 1974; Lamar et al. 1986; Lamar \& Douglass 1995; Piepjohn 2000; Braathen et al. 2011). This scenario is, therefore, considered highly unlikely.
In this perspective, it is relatively simple to explain the transition from basement rocks to Devonian sedimentary rocks across Wijdefjorden. The transition may be explained by preferential (glacial) erosion along the west-tilted lithostratigraphic boundary/unconformity between hard, intensely deformed and metamorphosed Palaeoproterozoic basement rocks and relatively weak, shale-rich Devonian sedimentary rocks, which merges with the seafloor just east of the mouth of Wijdefjorden (Fig. 3a-c, Supplementary Figs. S1, S2). Since basement rocks of the north-eastern and north-western terranes were both deformed into large northsouth-trending folds during the Caledonian Orogeny (e.g., Atomfjella Antiform and Bockfjorden Anticline; Gee \& Hjelle 1966; Gjelsvik 1979; Gee et al. 1992; Witt-Nilsson et al. 1998), the west-tilted unconformity and, therefore, the resulting erosional trough would trend north-south, that is, parallel to the Atomfjella Antiform and to Wijdefjorden. Note that this does not preclude further exploitation (upliftexhumation) of major north-south-trending basement ridges in subsequent tectonic events (e.g., Ellesmerian and Eurekan contraction, Devonian extension).

\section{Conclusion}

Seismic data north of Wijdefjorden show the presence of shallow (sone second TWT), tightly folded Caledonian basement rocks and of gently folded post-Caledonian (Devonian?) sedimentary strata to the west. Seismic interpretation in this area closely correlates with the geology of nearby onshore areas.

The data show no sign of faulting north of Wijdefjorden, and the top-basement reflection gradually deepens from seafloor level off the tip of Ny-Friesland to ca. one second (TWT) in the west. Because of the absence of clear evidence of faulting, the location and nature of the northern continuation of the Billefjorden Fault Zone remain uncertain, but the most probable explanation is that the fault dies out northwards in Wijdefjorden.

Nonetheless, the homogeneity of intra-basement seismic facies and the continuity and homogeneous character of the top-basement reflection suggest that the rheology of Caledonian basement rocks does not significantly vary across Wijdefjorden in Andrée Land (below Devonian Graben) and Ny-Friesland. The presence of a major, lithospheric terrane boundary between Ny-Friesland and Andrée Land is, therefore, highly questionable.

Regardless, much work is needed to further constrain tectonic relationships of basement rocks, the Billefjorden Fault Zone and related terrane boundaries in northern Spitsbergen, and acquiring new seismic data in this area (e.g., in Vestfjorden-Austfjorden-Wijdefjorden) may significantly help to resolve these relationships. 


\section{Acknowledgements}

The authors thank the Norwegian Petroleum Directorate for access to seismic data of the DISKOS database.

\section{Disclosure statement}

The author reports no conflict of interest.

\section{Funding}

This project was supported by the Research Council of Norway, the Tromsø Research Foundation and six industry partners through the Research Centre for Arctic Petroleum Exploration (ARCEx; grant no. 228107), the SEAMSTRESS project (grant no.287865) and the Centre for Earth Evolution and Dynamics (CEED; grant no. 223272).

\section{Data availability}

High-resolution versions of the figures are available on DataverseNO at doi.org/10.18710/LP3YMQ.

\section{References}

Allaart L., Müller J., Shomacher A., Rydningen T.A., Håkansson L., Kjellman S.E., Mollenhauer G. \& Forwick M. 2020. Late Quaternary glacier and sea-ice history of northern Wijdefjorden, Svalbard. Boreas 49, 417-437, doi: 10.1111 /bor.12435.

Bælum K. \& Braathen A. 2012. Along-strike changes in fault array and rift basin geometry of the Carboniferous Billefjorden Trough, Svalbard, Norway. Tectonophysics 546-547, 38-55, doi: 10.1016/j.tecto.2012.04.009.

Balashov Y.A., Larionov A.N., Gannibal L.F., Sirotkin A.N., Tebenkov A.M., Ryüngenen G.I. \& Ohta Y. 1993. An early proterozoic U-Pb zircon age from an Eskolabreen formation gneiss in southern Ny Friesland, Spitsbergen. Polar Research 12, 147-152, doi: 10.1111/j.1751-8369.1993. tb00429.x.

Braathen A., Bælum K., Maher H.D. Jr. \& Buckley S.J. 2011. Growth of extensional faults and folds during deposition of an evaporite-dominated half-graben basin; the Carboniferous Billefjorden Trough, Svalbard. Norsk Geologisk Tidsskrift 91, 137-160.

Braathen A., Osmundsen P.T., Maher H.D. Jr. \& Ganerød M. 2018. The Keisarhjelmen detachment records SilurianDevonian extensional collapse in northern Svalbard. Terra Nova 30, 34-39, doi: 10.1111/ter.12305.

Czuba W. 2007. 2.5-D seismic tomographic modelling of the crustal structure of north-western Spitsbergen based on deep seismic soundings. Marine Geophysical Researches 28, 213-233, doi: 10.1007/s.11001-007-9028-3.
Czuba W., Ritzmann O., Nishimura Y., Grad M., Mjelde R., Guterch A. \& Jokat W. 2004. Crustal structure of the continent-ocean transition zone along two deep seismic transects in north-western Spitsbergen. Polish Polar Research 25, 205-221.

Czuba W., Ritzmann O., Nishimura Y., Grad M., Mjelde R., Guterch A. \& Jokat W. 2005. Crustal structure of northern Spitsbergen along the deep seismic transect between the Molloy Deep and Nordaustlandet. Geophysical Journal International 161, 347-364, doi: 10.1111/j.1365-246X.2005.02593.x.

Dallmann W.K. 2015. Geoscience atlas of Svalbard. Norsk Polarinstitutt Rapportserie 148. Tromsø: Norwegian Polar Institute.

Dallmann W.K. \& Piepjohn K. 2018. Comment on "The Keisarhjelmen detachment records Silurian-Devonian extensional collapse in Northern Svalbard." Terra Nova 30, 319-321, doi: 10.1111/ter.12335.

Dallmann W.K. \& Piepjohn K. 2020. The architecture of Svalbard's Devonian basins and the Svalbardian Orogenic Event. Norges Geologiske Undersøkelse Bulletin, Special Publications 15. Trondheim: Geological Survey of Norway.

Dallmeyer R.D., Peucat J.J. \& Ohta Y. 1990. Tectonothermal evolution of contrasting metamorphic complexes in northwest Spitsbergen (Biskayarhalvøya): evidence from ${ }^{40} \mathrm{Ar} /{ }^{39} \mathrm{Ar}$ and $\mathrm{Rb}-\mathrm{Sr}$ mineral ages. Geological Society of America Bulletin 102, 653-663.

Eiken O. 1992. An outline of the northwestern Svalbard continental margin. In T.O. Vorren et al. (eds.): Arctic geology and petroleum potential. Vol. 2. Pp. 619-629. Amsterdam: Elsevier.

Fleming W.L.S. \& Edmonds J.M. 1941. Hecla Hoek rocks of New Friesland (Spitsbergen). Geological Magazine 78, 405-428.

Friend P.F., Harland W.B., Rogers D.A., Snape I. \& Thornley R.S. 1997. Late Silurian and early Devonian stratigraphy and probable strike-slip tectonics in northwestern Spitsbergen. Geological Magazine 134, 459-479.

Gee D.G., Björklund L. \& Stølen L.-K. 1994. Early Proterozoic basement in Ny Friesland-implications for the Caledonian tectonics of Svalbard. Tectonophysics 231, 171-182, doi: 10.1016/0040-1951(94)90128-7.

Gee D.G. \& Hjelle A. 1966. On the crystalline rocks of northwest Spitsbergen. Norsk Polarinstitutt Årbok 1964, 31-46.

Gee D.G. \& Page L.M. 1994. Caledonian Terrane Assembly on Svalbard: new evidence from ${ }^{40} \mathrm{Ar} /{ }^{39} \mathrm{Ar}$ Dating in $\mathrm{Ny}$ Friesland. American Journal of Science 294, 1166-1186, doi: 10.2475/ajs.294.9.1166.

Gee D.G., Schouenborg B., Peucat J.-J., Abakoumov S.A., Krasil'scikov A.A. \& Tebenkov A. 1992. New evidence of basement in the Svalbard Caledonides: early Proterozoic zircon ages from Ny-Friesland granites. Norwegian Journal of Geology 72, 181-190.

GeisslerW.H.\& JokatW.2004. Ageophysical study of the northern Svalbard continental margin. Geophysical Journal International 158, 50-66, doi: 10.1111/j.1365-246X.2004.02315.x.

Geissler W.H., Jokat W. \& Brekke H. 2011. The Yermak Plateau in the Arctic Ocean in the light of reflection seismic data-implication for its tectonic and sedimentary evolution. Geophysical Journal International 187, 1334-1362, doi: 10.1111/j.1365-246X.2011.05197.x. 
Gjelsvik T. 1979. The Hecla Hoek ridge of the Devonian Graben between Liefdefjorden and Holtefonna, Spitsbergen. Norsk Polarinstitutt Skrifter 167, 63-71.

Haremo P., Andresen A., Dypvik H., Nagy J., Elverøi A., Eikeland T.A. \& Johansen H. 1990. Structural development along the Billefjorden Fault Zone in the area between Kjellströmdalen and Adventdalen/Sassendalen, central Spitsbergen. Polar Research, 8, 195-216, doi: 10.3402/polar.v8i2.6812.

Harland W.B., Cutbill L.J., Friend P.F., Gobbett D.J., Holliday D.W., Maton P.I., Parker J.R. \& Wallis R.H. 1974. The Billefjorden Fault Zone, Spitsbergen: the long history of a major tectonic lineament. Norsk Polarinstitutt Skrifter 161. Oslo: Norwegian Polar Institute.

Harland W.B., Hambrey M.J. \& Waddams P. 1993. Vendian geology of Svalbard. Norsk Polarinstitutt Skrifter 193. Oslo: Norwegian Polar Institute.

Harland W.B., Scott R.A., Auckland K.A. \& Snape I. 1992. The Ny Friesland Orogen, Spitsbergen. Geological Magazine 129, 679-708.

Jakobsson M., Mayer L., Coackley B., Dowdeswell J.A., Forbes S., Fridman B., Hodnesdal H., Noormets R., Pedersen R., Rebesco M., Schenke H.W., Zarayskaya Y., Accettella D., Armstrong A., Anderson R.M., Bienhoff P., Camerlenghi A., Church I., Edwards M., Gardner J.V., Hall J.K., Hell B., Hestvik O., Kristoffersen Y., Marcussen C., Mohammad R., Mosher D., Nghiem S.V., Pedrosa M.T., Travaglini P.G. \& Weatherall P. 2012. The International Bathymetric Chart of the Arctic Ocean (IBCAO) Version 3.0. Geophysical Research Letters 39, L12609, doi: 10.1029/2012GL052219.

Ji S. \& Long C. 2006. Seismic reflection response of folded structures and implications for the interpretation of deep seismic reflection profiles. Journal of Structural Geology 28, 1380-1387, doi: 10.1016/j.jsg.2006.05.003.

Jokat W., Geissler W.H. \& Voss M. 2008. Basement structure of the north-western Yermak Plateau. Geophysical Research Letters 35, L05309, doi:10.1029/2007GL032892.

Kowalewski W., Rudowski S. \& Zalewski S.M. 1990. Seismoacoustic studies within Wijdefjorden, Spitsbergen. Polish Polar Research 11, 287-300.

Kubiak A. 2020. Structural analysis along seismic profiles trough late-Paleozoic deposits in Billefjorden and Sassenfjorden, Svalbard and their relation to the Billefjorden Fault Zone. Master's thesis, UiT The Arctic University of Norway, Tromsø.

Labrousse L., Elvevold S., Lepvrier C. \& Agard P. 2008. Structural analysis of high-pressure metamorphic rocks of Svalbard: reconstructing the early stages of the Caledonian orogeny. Tectonics 27, TC5003, doi: 10.1029/2007TC002249.

Lamar D.L. \& Douglass D.N. 1995. Geology of an area astride the Billefjorden Fault Zone, northern Dicksonland, Spitsbergen, Svalbard. Norsk Polarinstitutt Skrifter 197. Oslo: Norwegian Polar Institute.

Lamar D.L., Reed W.E. \& Douglass D.N. 1986. Billefjorden Fault Zone, Spitsbergen: is it part of a major Late Devonian transform? Geological Society of America 97, 1083-1088, doi: 0.1130/0016-7606(1986)97<1083:BFZSII>2.0.CO;2.

Major H. \& Nagy J. 1972. Geology of the Adventdalen map area. Norsk Polarinstitutt Skrifter 138. Oslo: Norwegian Polar Institute.
Manby G.M. 1990. The petrology of the Harkerbreen Group, Ny Friesland, Svalbard: protoliths and tectonic significance. Geological Magazine 127, 129-146, doi: 10.1017/ S0016756800013820.

Manby G.M. \& Lyberis N. 1992. Tectonic evolution of the Devonian Basin of northern Svalbard. Norsk Geologisk Tidsskrift 72, 7-19.

Manby G.M., Lyberis N., Chorowicz J. \& Thiedig F. 1994. Post-Caledonian tectonics along the Billefjorden Fault Zone, Svalbard, and implications for the Arctic region. Geological Society of America Bulletin 105, 201-216.

Mazur S., Czerny J., Majka J., Manecki M., Holm D., Smyrak A. \& Wypych A. 2009. A strike-slip terrane boundary in Wedel Jarlsberg Land, Svalbard, and its bearing on correlations of SW Spitsbergen with the Pearya terrane and Timanide belt. Journal of the Geological Society, London 166, 529-544, doi: 10.1144/0016-76492008-106.

McCann A.J. 2000. Deformation of the Old Red Sandstone of NW Spitsbergen; links to the Ellesmerian and Caledonian orogenies. In P.F. Friends \& B.P.J. Williams (eds.): New perspectives on the Old Red Sandstone. Pp. 567-584. London: Geological Society of London.

Michalski K., Lewandowski M. \& Manby G. 2012. New palaeomagnetic, petrographic and ${ }^{40} \mathrm{Ar} /{ }^{39} \mathrm{Ar}$ data to test palaeogeographic reconstructions of Caledonide Svalbard. Geological Magazine 149, 696-721, doi: 10.1017/S0016756811000835.

Murascov L.G. \& Mokin J.I. 1979. Stratigraphic subdivision of the Devonian deposits of Spitsbergen. Norsk Polarinstitutt Skrifter 167, 249-261.

Nergård A.P. 2020. Analyse av paleozoiske forkastninger og deres relasjon til devon-karbon avsetninger langs Sassenfjorden og Tempelfjorden, Svalbard, basert på multiverktoy land og fjord-datasett. (Analysis of Palaeozoic faults and their relationship to DevonianCarboniferous deposits along Sassenfjorden and Tempelfjorden, Svalbard, based on multitool land and fjord data set.) Master's thesis, UiT The Arctic University of Norway, Tromsø.

Nilsen T.H. \& Sylvester A.G. 1995. Strike-slip basins. In C. Busby \& R.V. Ingersoll (eds.): Tectonics of sedimentary basins. Pp. 425-457. Blackwell Science: Cambridge, MA.

Piepjohn K. 2000. The Svalbardian-Ellesmerian deformation of the Old Red Sandstone and the pre-Devonian basement in NW Spitsbergen (Svalbard). In P.F. Friend \& B.P.J. Williams (eds.): New perspectives on the Old Red Sandstone. Pp. 585-601. London: Geological Society of London Special Publications.

Ritzmann O. \& Jokat W. 2003. Crustal structure of northwestern Svalbard and the adjacent Yermak Plateau: evidence for Oligocene detachment tectonics and non-volcanic breakup. Geophysical Journal International 152, 139-159, doi: 10.1046/j.1365-246X.2003.01836.x.

Roy J.-C.L.G. 2007. La géologie du fossé des Vieux Grès Rouges du Spitzberg (archipel du Svalbard, territoire de l'Arctique)—synthèse stratigraphique, consequences paléoenvironnementales et tectoniques synsédimentaires. (Geology of the Old Red Sandstone graben in Spitsbergen [Svalbard Archipelago, Arctic]-stratigraphic synthesis, palaeoenvironmental consequences and synsedimentary tectonics.) PhD thesis, Pierre and Marie Curie University, Paris.

Skilbrei J.R. 1992. Preliminary interpretation of aeromagnetic data from Spitsbergen, Svalbard Archipelago 
$\left(76^{\circ}-79^{\circ} \mathrm{N}\right)$ : implications for structure of the basement. Marine Geology 106, 53-68.

Smyrak-Sikora A.A., Johannessen E.P., Olaussen S., Sandal G. \& Braathen A. 2018. Sedimentary architecture during Carboniferous rift initiation-the arid Billefjorden Trough, Svalbard. Journal of the Geological Society, London 176, 225-252, doi: 10.1144/jgs2018-100.
Sylvester A.G. 1988. Strike-slip faults. Geological Society of America Bulletin 100, 1666-1703, doi: 10.1130/0016-7606(1988) 100<1666:SSF>2.3.CO;2.

Witt-Nilsson P., Gee D.G. \& Hellman F.J. 1998. Tectonostratigraphy of the Caledonian Atomfjella Antiform of northern Ny Friesland, Svalbard. Norsk Geologisk Tidsskrift $78,67-80$. 